\title{
The Implementation of Organization Culture and their Relationship to the Working Satisfaction of Teacher at the Health Asy-Syifa School Aceh Indonesia
}

\author{
Syukriadi \\ Department of Educational Administration \\ Syiah Kuala University, Indonesia \\ yusrizal_fipunsyiah@yahoo.com
}

\author{
Yusrizal \\ Department of Educational Administration \\ Syiah Kuala University, Indonesia \\ yusrizal_fipunsyiah@yahoo.com
}

\author{
Bahrun \\ Department of Educational Administration \\ Syiah Kuala University, Indonesia \\ yusrizal_fipunsyiah@yahoo.com
}

\begin{abstract}
The purpose of this study is to determine the formulation of organizational culture programs on job satisfaction, implementation organizational culture on job satisfaction, and obstacles faced by principals in the application of organizational culture to job satisfaction. This study uses descriptive method with a qualitative approach. Data collection techniques: observation, interviews, and documentation studies. The subject of study was the principal, and the teachers. The results of this study indicate are: (1) the formulation mechanism begins with the implementation of deliberations between stakeholders such as vice principals, and teachers; programs compiled, longterm, medium-term and short-term programs, and all of these programs are guided by the Ministry of Education and Culture regulations and instructions from the Aceh Province education office; and (2) leadership apply the organizational culture to themselves as an example for their subordinates and principals to take approaches to improve teacher job satisfaction. For teachers who work very well, they will be given prizes or support in the form of advancing the teacher's name to participate in principalship candidate and promoted.
\end{abstract}

Keywords: organization culture, principals, teachers satisfaction

\section{INTRODUCTION}

In this era of globalization which are many of change, where are that change happened vary quickly and is very hardest to predict but has a big impact on the future of the organization, the culture flexible of organizational culture is increasingly relevant. The strategy in anticipating changes that will be made by an organization also needs to consider the cultural aspects that have existed so far, whether the designed strategy matches the values that exist, or precisely the values that exist actually become counterproductive for the organization on its way forward. Managers, especially those at the top level, must be aware of the importance of understanding the culture of the organization because of its enormous influence on member behavior. Organizational culture can also be used as a concept in developing a change strategy or developing the organization it leads.

Organizational culture, especially in an institution, feels an important role. Because it will make the institution flexible, flexible and elastic, as a culture that will never experience a setback and will be very perfect if combined with religion that originates in Divine Revelation. Not a few who say that religion is included in the scope of culture. Even so if religious people are able to apply religious teachings in their cultural life.

If there are government programs that experience obstacles, usually the scapegoat is culture. The values that become the content of the program have not been entrenched, or culture is considered difficult to change. If there is a new value that its application requires changes and changes, the authority is considered to be detrimental to its interests, then the basis for rejection of the new value is that culture is not in accordance with the personality and culture of the nation.

Organizational studies provide an understanding of the organization as a subject and cultural object. If the study of organizational behavior is based on the assumption that the organization behaves on its own, in contrast to the behavior of the people who make it, then in line with that, the organization also has its own culture (organizational culture), in contrast to the culture of the people concerned with it. Organizational culture is formed from the characteristics of the organization as its object and subject. The purpose of this study is to determine the formulation of organizational culture programs on job satisfaction, the implementation of organizational culture on job satisfaction, and the constraints faced by principals in the application of organizational culture to job satisfaction.

\section{METHODS}

Research used is qualitative research whose data will be presented in descriptive analysis. Qualitative research methods can be interpreted as a research method based on the philosophy of positivism / enterpretif, used to examine the condition of a natural object, (as opposed to experiment) where the researcher as a key instrument, the data collection technique is triangulated (combined) data analysis is inductive, and the results of qualitative research emphasize meaning rather than generalization (Sugiyono, 2015). In accordance with the above opinion, the main subject of this research is the researcher itself because the researcher as a key instrument with triangulation data 
collection techniques or a combination of several sources. Qualitative research is a research used to express symptoms thoroughly and in accordance with the context by collecting data from natural backgrounds by utilizing researchers as a powerful of instrument.

The purpose the qualitative objectives are to achieve an understanding of how people feel in their life processes, give meaning, and describe how people interpret their experiences. Data collection can be done in various settings, various sources, and various ways. When viewed from settings, its data can be collected in a natural setting (naturalsetting), the laboratory experimental method, in schools with education personnel and education, at home with various respondents, at a seminar, discussion, on the road and others. The data and information that have been obtained by the next researcher are analyzed and interpreted from the beginning of the research to the end of the research by referring to the theoretical basis that relates to the problem under study. Data analysis in qualitative research is done by classifying, directing, disposing of unnecessary, and organizing data (reducing data), summarizing the main things (data display) and drawing conclusions (data verification).

\section{RESULTS AND DISCUSSION}

Implementation of Program in Organizational Culture by the Principal and its Relation to Teacher Job Satisfaction

The results of this study indicate that, the program of implementing organizational culture by the principal and its relation to job satisfaction, is very helpful in achieving the goals of education itself which is in accordance with the mandate of the law that is to educate the nation's children. this program is inseparable from the leadership of the principal, because creating a culture within the organization is not easy, because from this organizational culture we hope to increase job satisfaction with teachers. and all of that is the responsibility of the principal as the manager and supervisor of the school he leads.

The principal is responsible for managing the school by implementing national education standards universally in the education unit. It also remembers that the school is a place to cultivate policies that have been determined and must be followed by members of the school organization. Permendikbud No. 19 / 2007 as follows: schools/madrasah formulate and define the vision and develop it. Vision of school/madrasah: (1) be used as an aspiration with school/madrasah citizens and all interested parties in the future; (2) able to provide inspiration, motivation, and strength to the citizens of the school/madrasah and all interested parties; (3) formulated based on input from various residents of schools/madrasas and interested parties, in line with the vision of the above institutions and the vision of national education; (4) decided by a meeting of the board of educators led by the headmaster/madrasah by paying attention to the input of the school/madrasah committee; (5) socialized to citizens of schools/madrasas and all interested parties; and (6) periodically reviewed and reformulated in accordance with developments and challenges in the community.

Implementation of Organizational Culture by the School Principal and its Relation to Teacher Job Satisfaction

Furthermore, based on the results of field research, it is explained that the school organization can be implemented with well then there is a system of division of tasks in accordance with their respective capabilities, this task sharing system is carried out with the intention of school personnel capable of carrying out tasks and focusing so as to make it easier to control when experiencing obstacles. That the policy policy of the leader will be very anchored on the success of an organization including the educational organization.

Coordination and cooperation in the organization will be more effective in achieving the desired goals, this happens because the duties and responsibilities of the principal as the leader in the education unit will be lighter. This is in accordance with Yudhaningsih (2011) opinion that organizational effectiveness as a level can realize its goals. Meanwhile, according to Handoko Yudhaningsih (2011) Work effectiveness consists of the words effectiveness and work. Effectiveness is the ability to choose the right or the right equipment for achieving the stated goals.

Obstacles Faced by School Principals in the Application of Organizational Culture and its Relation to Teacher Job Satisfaction

From the results of the study it was found that there were obstacles to school principals in implementing organizational culture and would certainly have a major impact on teacher job satisfaction. the obstacles faced are, it takes time to form a habit, because one's culture can certainly change but requires a long time and processes first. In a school led by the headmaster has a variety of characters, culture, ethnicity, fields of knowledge experienced by a teacher. This is an obstacle that needs to be resolved by the school principal and of course this all takes time and is very draining and thoughtful.

\section{CONCLUSION}

Program of implementing organizational culture by the principal and its relation to teacher job satisfaction. Regulated or formulated at the beginning of the year before carrying out teaching and learning activities at the beginning of the year or the beginning of the semester, and evaluated at the end of the semester, and in the form of monitoring the implementation of culture a team is formed to monitor each day so that the organizational culture program can run smoothly.

The implementation of the organizational culture by the school principal and its relation to teacher job satisfaction begins with giving directions at the beginning of each semester. In carrying out school activities, the principal applies the family approach, reward, and reprimand. The activities carried out have not been all instruments and are running as expected, 
because the schedule for the implementation of the activities is not all according to the plan and the frequency of supervision is not in accordance with the planned program planning. The obstacles faced by the principal in the application of organizational culture and of course will have a major impact on teacher job satisfaction. The obstacles faced are, it takes time to form a habit, because one's culture can certainly change but requires a long time and processes first.

\section{REFERENCES}

[1] Andriani, N. 2006. Effect of Organizational Climate on Employee Performance of Bank Merger Malang. Infestation Journal, 2(1), 49-62.

[2] Ardiansyah, F., and Purba, S. 2015. Effect of Job Satisfaction on Teacher Performance with Career Motivation as Moderation and Career Satisfaction Variables as Mediation Variables in YP IPPI. DeReMa Journal of Management, 10(1), 32-34.

[3] Fahmi, I. 2014. Organizational Behavior (Theory, Application, Case). Bandung: Alfabeta.

[4] Herawan, K. 2015. Effect of Organizational Culture on Employee Job Satisfaction Study at PT. Bank Rakyat Indonesia (Persero) Malang Kawi City Branch Office. Journal of Business Administration, 1(1), 102-110.

[5] Juni, P. D. 2014. Teacher's Performance and Professionalism. Bandung: Alfabeta.

[6] Karwati, E., and Priansa, D. J. 2013. Principal Performance and Professionalism. Bandung: Alfabeta.

[7] Light, S., and Kiki. 2015. The Influence of Organizational Climate on Employee Level Implementation Performance in the Operations Division of PT Pusri Palembang. Islamic Psychology Journal, 1(1) 23-24. 